Original Research Article

\title{
A cross sectional observational study to find the difference in occurrence of muscle related adverse effects of statins among geriatric and non-geriatric patients
}

\author{
Monica Aggarwal ${ }^{1}$, Shivani Juneja ${ }^{1 *}$, Muskan Goyal ${ }^{2}$, Tariq Khurana ${ }^{3}$
}

\begin{abstract}
${ }^{1}$ Department of Pharmacology, ${ }^{2}$ MBBS Student, ${ }^{3}$ Department of Medicine, ESIC Medical College and Hospital, NIT-3, Faridabad 121001, Haryana, India

Received: 11 July 2018

Accepted: 04 August 2018

*Correspondence to:

Dr. Shivani Juneja,

Email: docshivani28@ gmail.com

Copyright: (C) the author(s), publisher and licensee Medip Academy. This is an openaccess article distributed under the terms of the Creative Commons Attribution NonCommercial License, which permits unrestricted noncommercial use, distribution, and reproduction in any medium, provided the original work is properly cited.
\end{abstract}

\begin{abstract}
Background: Statins are effectively used for the treatment of dyslipidemias in geriatric patients. The geriatric patients are more vulnerable to experience consequences of drug intensification leading to the manifestation of adverse effects, such as muscle related adverse effects (MRAE) with statins use. The main objective was to find the difference in the occurrence of MRAE of statins among geriatric and non-geriatric users.

Methods: This was a cross-sectional, observational comparative study in which MRAE associated with statins and relevant patient information was noted. Creatine phosphokinase (CPK) levels which are considered as a marker for statin induced muscle damage were obtained for all patients. The different parameters were compared among geriatric and non-geriatric statin users.

Results: Sixty one patients, 28 geriatric ( $\geq 60$ years) and 33 non-geriatric $(<60$ years) statin users were enrolled in this study. Ten (38\%) geriatric statin users as compared to $6(20 \%)$ non-geriatric statin users were found to have MRAE (P = $0.207)$. No significant difference in the occurrence of MRAE among geriatric and non-geriatric statin users was found.

Conclusions: The results obtained from the present study suggest that statins are relatively safe, even in older people. There was no evidence to suggest an increased risk of MRAE in geriatric patients receiving statin therapy as compared to non- geriatric patients.
\end{abstract}

Keywords: Geriatric, Myopathy, Statins

\section{INTRODUCTION}

Statins or 3-hydroxy-3-methylglutaryl coenzyme A reductase inhibitors (HMG-CoA reductase inhibitors) are most effective in reducing LDL-C and are widely used for the prevention of cardiovascular disease (CVD). ${ }^{1}$ Most common adverse effect of statins i.e. muscle related adverse effects (MRAE) ranges from a painless increase in serum creatine phosphokinase (CPK), to a mild muscular discomfort (myalgia), to a potentially life-threatening rhabdomyolysis raising $\mathrm{CPK}$ levels to beyond ten times the upper limit of normal, leading to renal dysfunction or failure. $^{2}$

The geriatric patients are more likely to experience consequences of drug intensification leading to the manifestation of adverse effects, such as statin related MRAE. It is because of various risk factors like depressed renal and hepatic functions, wasting, likelihood of multisystem disease and polypharmacy leading to drug interactions with statins. ${ }^{3}$ Literature describes $10-15 \%$ of prevalence of MRAE but specific studies on geriatric age group are lacking and in India also, there is hardly any 
study describing the magnitude of this problem. Large clinical trials have also not addressed this issue because they generally exclude geriatric patients and undertake drug safety as secondary parameter. ${ }^{4}$ One study conducted in India has shown gender differences in occurrence of MRAE among geriatric patients but no comparison was done with Non-geriatric patients. ${ }^{5}$ In the relative vacuum of specific data on relationships between advancing age, statin use, and muscle dysfunction, the main objective of this observational study is to find the difference in occurrence of MRAE of statins in geriatric $(\geq 60$ years of age) and non- geriatric ( $<60$ years of age) statin users.

\section{METHODS}

The study was started after obtaining permission from the Institutional Ethics Committee. All patients were explained the purpose and rationale of the study and a written informed consent was obtained from all the patients prior to enrolling them in the study.

\section{Study design and participants}

This study was designed as single centre, cross sectional, observational study conducted in the Department of Medicine, and the Department of Pharmacology of the ESIC Medical College, Faridabad, India.

Geriatric ( $\geq 60$ years of age) and non-geriatric statin $(<60$ years of age) users undergoing treatment in the Department of Medicine were screened and enrolled in the study. Patients with a history of recent trauma, active arthritis of any type, acute infectious diseases and other conditions presenting with myalgia and bodily pains were excluded from the study.

Relevant patient information such as statin received, indication of statin, duration of treatment, any concomitant medication and MRAE associated with statin use were noted. CPK levels were obtained for all patients as this is considered as the marker for statin induced muscle damage. Data obtained from all patients was noted in the case report form.

Following definitions were used to cover the spectrum of MRAE associated with statin use: Myopathy - Any disease of muscle, Myalgia - Muscle aches or weakness without CPK elevation, Myositis - Muscle symptoms with increased CPK, Rhabdomyolysis - Muscle symptoms associated with marked CPK elevations, typically substantially over ten times upper limit of normal.

\section{Statistical analysis}

For data analysis, patients were divided into two groups i.e. Geriatric ( $\geq 60$ years of age) and non- Geriatric $(<60$ years of age). We tried to enrol as many as statin users possible during the period of this study as previous estimates are not there in the literature. The data was analysed using SPSS version 20, Epi info software. Data were represented as percentages, mean \pm standard deviation, and categorical data were analysed using t-test and chi-square test wherever applicable.

\section{RESULTS}

Sixty one patients, 28 geriatric ( $\geq 60$ years) and 33 nongeriatric $(<60$ years) statin users were enrolled in this study. Various characteristics of geriatric and non-geriatric statin users and comparison of various parameters among them are given in Table 1 .

Table 1: Comparison of various parameters among geriatric and non-geriatric statin users.

\begin{tabular}{|c|c|c|c|}
\hline Parameter & $\begin{array}{l}\text { Geriatric } \\
\text { statin user } \\
\mathrm{N}=\mathbf{2 8}\end{array}$ & $\begin{array}{l}\text { Non-geriatric } \\
\text { statin user } \\
\mathbf{N}=\mathbf{3 3}\end{array}$ & $\begin{array}{l}P \\
\text { value }\end{array}$ \\
\hline Age (years) & $62.2 \pm 2.85$ & $47.3 \pm 7.11$ & $\begin{array}{l}<0.001 \\
\text { (t-test) }\end{array}$ \\
\hline $\begin{array}{l}\text { Male/ } \\
\text { female }\end{array}$ & $16 / 12$ & $15 / 18$ & $\begin{array}{l}0.514 \\
\text { (t-test) }\end{array}$ \\
\hline Weight (kg) & $58.1 \pm 7.67$ & $57.8 \pm 8.46$ & $\begin{array}{l}0.451 \\
\text { (t-test) }\end{array}$ \\
\hline BMI $\left(\mathrm{kg} / \mathrm{m}^{2}\right)$ & $22.6 \pm 1.77$ & $21.9 \pm 1.87$ & $\begin{array}{l}0.866 \\
\text { (t-test) }\end{array}$ \\
\hline $\begin{array}{l}\text { Mean dose of } \\
\text { Atorvastatin } \\
(\mathrm{mg})\end{array}$ & $20 \pm 0$ & $20 \pm 0$ & $\begin{array}{l}0.000 \\
(t-t e s t)\end{array}$ \\
\hline $\begin{array}{l}\text { Mean } \\
\text { duration of } \\
\text { use of } \\
\text { Atorvastatin } \\
\text { (days) }\end{array}$ & $13.4 \pm 16.96$ & $9.3 \pm 8.69$ & $\begin{array}{l}0.003 \\
\text { (t-test) }\end{array}$ \\
\hline $\begin{array}{l}\text { CPK levels } \\
\text { (units/L) }\end{array}$ & $\begin{array}{l}183.6 \pm 133 \\
93\end{array}$ & $149.2 \pm 115.26$ & $\begin{array}{l}0.107 \\
\text { (t-test) }\end{array}$ \\
\hline $\begin{array}{l}\text { No. of } \\
\text { concomitant } \\
\text { drugs }\end{array}$ & $3.0 \pm 0.84$ & $3.3 \pm 0.76$ & $\begin{array}{l}0.912 \\
\text { (t-test) }\end{array}$ \\
\hline $\begin{array}{l}\text { No. of } \\
\text { patients with } \\
\text { history of } \\
\text { CAD }\end{array}$ & 26 & 32 & $\begin{array}{l}0.883 \\
\text { (Chi- } \\
\text { square) }\end{array}$ \\
\hline $\begin{array}{l}\text { No. of } \\
\text { patients with } \\
\text { history of } \\
\text { hypertension }\end{array}$ & 10 & 13 & $\begin{array}{l}0.978 \\
\text { (Chi- } \\
\text { square) }\end{array}$ \\
\hline $\begin{array}{l}\text { No. of } \\
\text { patients with } \\
\text { history of } \\
\text { T2DM }\end{array}$ & 4 & 3 & $\begin{array}{l}0.817 \\
\text { (Chi- } \\
\text { square) }\end{array}$ \\
\hline
\end{tabular}

In this study, patients from both the groups were taking Atorvastatin in a dose of $20 \mathrm{mg}(\mathrm{P}=0.000 \mathrm{t}$-test $)$. The mean duration of statin use was $13.4 \pm 16.96$ months in geriatric patients vs. $9.3 \pm 8.69$ months in non-geriatric patients, $\mathrm{P}=$ 0.003 , t- test). The mean number of concomitant drugs was $3 \pm 0.84$ in geriatric patients vs. $3.3 \pm 0.76$ months in nongeriatric patients $(\mathrm{P}=0.912$, t-test $)$. The most common 
concomitant drugs were aspirin and clopidogrel in both groups. Ten (38\%) geriatric statin users vs $6(20 \%)$ nongeriatric statin users were found to have MRAE $(\mathrm{P}=0.207$, Chi-square test, Table 2). The difference in the occurrence of MRAE among geriatric and non-geriatric statin users was found to be statistically insignificant. Of 10 geriatric patients with MRAE, 8 patients had myalgia, 2 had myositis, 11 patients had asymptomatically elevated CPK levels (without myalgia). Distribution of different types of MRAE is given in Figure 1.

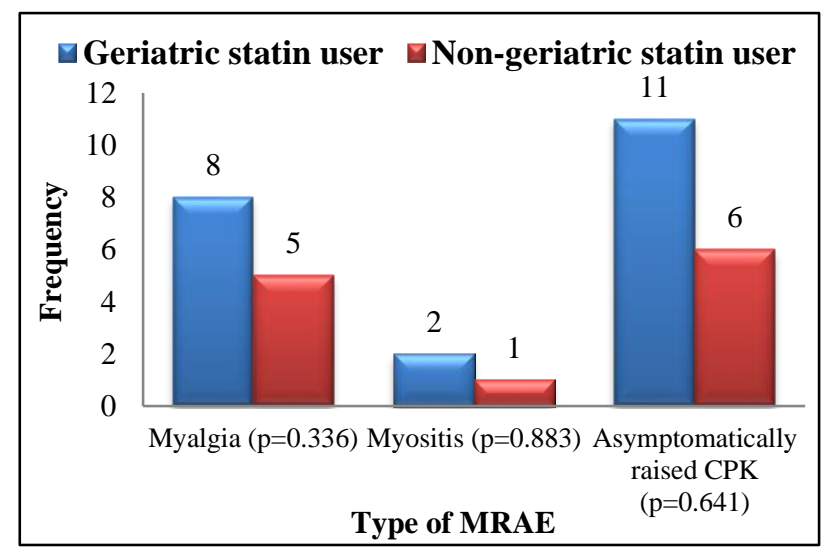

Figure 1: Comparison of different types of muscle related adverse effects among geriatric and nongeriatric statin users.

Thirteen patients ( 8 geriatric and 5 non-geriatric patients) developed myalgia with a median duration of 12 months from the start of therapy. The difference in the duration of onset of myalgia from the start of therapy was not found to be statistically significant among geriatric and nongeriatric statin users $(P=0.07$, Table 2). Various parameters were compared between patients who developed MRAE and who did not develop MRAE. Table 2 summarises the characteristics and comparison of various parameters between statin users who developed MRAE with those who did not develop MRAE.

\section{Creatine phosphokinase levels}

Thirty three statin users were found to have raised CPK levels (21 in geriatric statin users vs. 12 non-geriatric statin users, $\mathrm{P}=0.01$, Chi-square test, Table 1). The mean CPK levels in all 61 patients were $165 \pm 124.32$ units/L (minimum 45 units/L, maximum 431units/L). The difference in CPK levels among geriatric and non-geriatric users was not found to be statistically insignificant $(183.6 \pm 133.93$ units/L in geriatric patients vs. $149.2 \pm 115.26$ units/L in non-geriatric patients, $\mathrm{P}=0.107$, t-test, Table 1).

No significant difference was observed in CPK levels between statin users who developed MRAE and who did not develop MRAE, i.e., 194.2 \pm 126.02 units/L versus 156.4 \pm 122.98 units/L P $=0.575$ (t-test).
Table 2: Comparison of various parameters among subjects who developed muscle related adverse effects (MRAE) and those who did not develop MRAE.

\begin{tabular}{|c|c|c|c|}
\hline Parameter & $\begin{array}{l}\text { Statin user } \\
\text { with MRAE } \\
(\mathbf{N}=16)\end{array}$ & $\begin{array}{l}\text { Statin user } \\
\text { without MRAE } \\
(\mathrm{N}=45)\end{array}$ & $P$ value \\
\hline Age (years) & $58.1 \pm 6.42$ & $52.2 \pm 9.15$ & $\begin{array}{l}0.018 \\
\text { (t-test) }\end{array}$ \\
\hline Weight (kg) & $57.8 \pm 6.28$ & $58.2 \pm 8.42$ & $\begin{array}{l}0.123 \\
\text { (t-test) }\end{array}$ \\
\hline BMI $\left(\mathrm{kg} / \mathrm{m}^{2}\right)$ & $22.4 \pm 1.19$ & $22.1 \pm 1.94$ & $\begin{array}{l}0.083 \\
\text { (t-test) }\end{array}$ \\
\hline $\begin{array}{l}\text { Mean dose of } \\
\text { Atorvastatin } \\
(\mathrm{mg})\end{array}$ & $20 \pm 0$ & $20 \pm 0$ & $\begin{array}{l}0.000 \\
\text { (t-test) }\end{array}$ \\
\hline $\begin{array}{l}\text { Mean } \\
\text { duration of } \\
\text { use of } \\
\text { Atorvastatin } \\
\text { (days) }\end{array}$ & $18.7 \pm 19.32$ & $7.9 \pm 8.70$ & $\begin{array}{l}0.000 \\
(t-t e s t)\end{array}$ \\
\hline $\begin{array}{l}\text { CPK levels } \\
\text { (units/L) }\end{array}$ & $194.2 \pm 133.93$ & $156.4 \pm 122.98$ & $\begin{array}{l}1.503(\mathrm{t}- \\
\text { test })\end{array}$ \\
\hline $\begin{array}{l}\text { No. of } \\
\text { patients with } \\
\text { history of } \\
\text { CAD }\end{array}$ & 14 & 44 & $\begin{array}{l}1.182 \\
\text { (Chi- } \\
\text { square) }\end{array}$ \\
\hline $\begin{array}{l}\text { No. of } \\
\text { patients with } \\
\text { history of } \\
\text { hypertension }\end{array}$ & 10 & 13 & $\begin{array}{l}0.978 \\
\text { (Chi- } \\
\text { square) }\end{array}$ \\
\hline $\begin{array}{l}\text { No. of } \\
\text { patients with } \\
\text { history of } \\
\text { T2DM }\end{array}$ & 5 & 2 & $\begin{array}{l}0.010 \\
\text { (Chi- } \\
\text { square) }\end{array}$ \\
\hline
\end{tabular}

\section{DISCUSSION}

This study was planned to explore the difference in the occurrence of statins associated MRAE among geriatric and non-geriatric patients. All the patients in this study were taking atorvastatin in a dose of $20 \mathrm{mg}$. This may be due to the fact that no other preparation of statin is available in the hospital pharmacy. This finding is similar to that of study done by Choudhry et al, in which they found that atorvastatin accounts for about $90 \%$ of prescriptions in India. ${ }^{6}$

In this study, $10(38 \%)$ geriatric statin users were found to have MRAE and this percentage is consistent with already described prevalence in literature, i.e. $10 \%-15 \% .^{6,7}$ However, the difference in the occurrence of MRAE among geriatric and non-geriatric users was found to be statistically insignificant. Also, the difference in the duration of onset of myalgia was not found to be statistically significant among geriatric and non-geriatric statin users. Similarly, this difference was insignificant in the patients who developed MRAE in comparison to those who did not develop MRAE. In contrary to this, there was a significant difference in the mean duration of use of statins among those who developed MRAE than those who 
did not develop MRAE. This difference in the mean duration of use was somehow not seen in this study where statin users with MRAE were compared with statin users without MRAE. ${ }^{5}$

It has been widely reported that advancing age has been associated with increased risk of statin-induced muscle disorder across the entire spectrum, as well as with a significantly greater incidence of the more severe forms of this disorder reported among the oldest groups of statin users. ${ }^{8-10}$

The risk of muscle damage with statins increases with age over 70 years and with age-associated factors such as polypharmacy, comorbidity and sarcopenia (low skeletal muscle mass and function). Statin myopathy is likely to have a greater impact in older people, with limited musculoskeletal reserve, than in younger people, who generally have more muscle mass and strength and better mobility. ${ }^{11}$ In this study, however, no significant difference was found in the body mass index of geriatric vs nongeriatric patients.

Thirty three statin users (21 geriatric and 12 non geriatric) were found to have raised CPK levels. Though, no significant difference was observed in CPK levels between statin users who developed MRAE and who did not develop MRAE. Our finding is similar to that of study done by Mckenney et al, where they reported that muscular symptoms may be associated with or without CPK elevations. $^{2}$ The baseline levels of CPK were not taken in this study as the statins were already a part of ongoing therapy. So, on no grounds, comparison in CPK levels could be made. We found in literature that CPK levels may be raised due to other reasons than statins alone. They can be hypothyroidism, cushing's syndrome, hyponatremia, strenuous exercise, beta blockers, angiotensin receptor blockers, fibrates and so many others.

In the elderly population, statin induced myopathy leads to reduction in compliance as a result of the development of 'non-significant' myalgia. The second is the potential impairment or lost of activities of daily living secondary to myopathy-related pain or weakness, or both. Loss of independence is associated with increased morbidity and mortality as well as a reduction in the quality of life. ${ }^{11-13}$ This is further compounded by the great difficulty in differentiating pre-existing musculoskeletal pain and weakness due to frailty from those caused by statins. In addition to all the above, elderly patients may themselves be a significant barrier to the diagnosis of statin induced myopathy as they are more reluctant to report pain, describing pain as 'discomfort', 'ache', or 'hurting'. There is a tendency for the elderly patients to dismiss pain or weakness as part of the natural process of aging. There may also be a reluctance to report pain to their physicians for fear of more tests and treatments (ADR bulletin). ${ }^{14,15}$ However, in this study, there is no evidence of noncompliance or non-reporting of adverse effects.
In this study no correlation was found between comorbid conditions like coronary artery disease (CAD), type 2 diabetes mellitus, hypertension and severity of MRAE. In contrary to this, many studies with diabetic patients aged 65 years or older prescribed lipid lowering agents reported more than five times risk for hospitalization due to rhabdomyolysis than younger counterparts. This was attributed to existence of multiple risk factors for myopathy such as the use of concomitant medication, the presence of some disorders such as diabetes mellitus and small body frame (frailty), age related decline in renal and hepatic function, which in turn increased the risk for muscle complain in the elderly. ${ }^{16}$ However in this study there was no correlation between concomitant medication and severity of MRAE.

The results of our study are however consistent with findings of a systematic review. ${ }^{17}$ The main objective of the review was to provide reliable estimates of the risks of myopathy in the older person. Only one trial, PROSPER, specifically studied the elderly population; the remaining trials considered the older person as part of their subgroup analyses. The trials assessed in the systematic review showed little or no evidence of a difference in risks between treatment and placebo groups, with regard to myalgia, combined muscle adverse events (myopathy) or rhabdomyolysis. No trial reported an increased rate of death in older people taking statins. The results obtained from the present review suggests that statins are relatively safe in the older population, in terms of muscle adverse effects. Nothing suggested an increased risk of myopathy in the older adult receiving statin therapy.

It has been seen that lipophilic statins (Atorvastatin) have a higher propensity than hydrophilic statins to cause myopathy as an adverse effect because of their greater solubility in the tissues. Authors found no evidence of this effect in this population. This contradicts the results found in the literature, which show that hydrophilic statins are associated with a reduced risk of myopathy compared with lipophillic statins. ${ }^{17,18}$ Comparing atorvastatin doses in the CARDS and MIRACL studies (10mg vs. $80 \mathrm{mg}$ ), the risks of myopathy were increased almost threefold in the latter. It is interesting to note that simvastatin, the most lipophilic statin, had the same risks, even when used in low doses, in the $4 \mathrm{~S}$ trial as high-dose atorvastatin in MIRACL. ${ }^{18}$ The different doses employed in the intervention could possibly account for this difference as some studies used maximal doses and studies have shown that myopathy is dose dependent. ${ }^{13}$ However, in this study all patients were treated with a standard dose of $20 \mathrm{mg}$ of atorvastatin (procured from hospital pharmacy), therefore, maximal dose effects could not be studied.

Limitations of the study includes no follow up was done Authors did not obtain muscle biopsy for patients who had MRAE, however, authors obtained CPK levels for all study participants. Myalgia is a subjective symptom and pain perception may vary from patient to patient. 


\section{CONCLUSION}

There is no significant difference in MRAE between geriatric and non-geriatric patients. However, due to cross sectional nature of this study and other limitations, results cannot be generalised and need to be validated further.

\section{ACKNOWLEDGEMENTS}

Authors would like to knowledge about this study that this is the first study in India which attempts to find difference in the occurrence of adverse effects of statins between geriatric and non-geriatric patients.

Funding: No funding sources Conflict of interest: None declared

Ethical approval: The study was approved by the Institutional Ethics Committee

\section{REFERENCES}

1. Verri V, Cunha AB, Tessarolo LE, Carneiro RC, Romeo LJ. Reduction of myocardial ischaemia with Simvastatin in addition to conventional treatment in patients with chronic coronary artery disease. Rev port cardiol. 2004;23:1089-105.

2. McKenney JM, Davidson MH, Jacobson TA, Guyton JR. National Lipid Association Statin Safety Assessment Task Force. Final conclusions and recommendations of the national lipid association statin safety assessment task force. Am J Cardiol. 2006;97:89C-94C.

3. Alexander KP, Blazing MA, Rosenson RS, Hazard E, Aronow WS, Smith SC Jr, et al. Management of hyperlipidemia in older adults. J Cardiovasc Pharmacol Ther. 2009;14:49-58.

4. Sathasivam S. Statin induced myotoxicity. Eur J Intern Med. 2012;23:317-24.

5. Singh H, Chakrawarti A, Guruprasad P, Singh H, Gupta YK. Difference in occurrence of muscle-related adverse effects of statins among male and female geriatric patients: A cross-sectional observational study. Niger Postgrad Med J. 2016;23(4):202-8.

6. Choudhry NK, Dugani S, Shrank WH, Polinski JM, Stark CE, Gupta R, et al. Despite increased use and sales of statins in India, per capita prescription rates remain far below high-income countries. Health Aff (Millwood). 2014;33:273-82.

7. Abd TT, Jacobson TA. Statin-induced myopathy: A review and update. Expert Opin Drug Saf. 2011;10:373-87.
8. Bays H. Statin safety: An overview and assessment of the data-2005. Am J Cardiol. 2006;97:6C-26C.

9. Pasternak RC, Smith SC, Bairey-Merz CN, Grundy SM, Cleeman JI, Lenfant C. ACC/AHA/NHLBI clinical advisory on the use and safety of statins. J Ame Colle Cardiol. 2002 Aug 7;40(3):567-72.

10. Alexander KP, Blazing MA, Rosenson RS, Hazard E, Aronow WS, Smith Jr SC, et al. Management of hyperlipidemia in older adults. J Car Pharmacol Therapeu. 2009 Mar;14(1):49-58.

11. Bhardwaj S, Selvarajah S, Schneider EB. Muscular effects of statins in the elderly female: a review. Clinical Interventions in Aging. 2013;8:47-59.

12. Pasternak RC, Smith SC Jr, Bairey-Merz CN, Grundy SM, Cleeman JI, Lenfant C. ACC/AHA/NHLBI clinical advisory on the use and safety of statins. Circulation. 2002;106:1024-8.

13. Morgan TK, Williamson M, Pirotta M, Stewart K, Myers SP, Barnes J. A national census of medicines use: a 24-hour snapshot of Australians aged 50 years and older. Med J Aust. 2012;196:50-3.

14. Gnjidic D, Le Couteur DG, Blyth FM, Travison T, Rogers K, Naganathan V, et al. Statin use and clinical outcomes in older men: a prospective populationbased study. BMJ Open. 2013;3:e002333.

15. Padala KP, Padala PR, McNeilly DP, Geske JA, Sullivan DH, Potter JF. The effect of HMG-CoA reductase inhibitors on cognition in patients with Alzheimer's dementia: a prospective withdrawal and rechallenge pilot study. Am J Geriatr Pharmacother. 2012;10:296-302.

16. Tomlinson SS, Mangione KK. Potential adverse effects of statins on muscle. Phys Ther. 2005;85:45965.

17. Sathasivam. Statin induced myotoxicity. Eur J Intern Med. 2012;23:317-24.

18. Iwere RB, Hewitt J. Myopathy in older people receiving statin therapy: a systematic review and metaanalysis. Br J Clin Pharmacol. 2015;80:363-71.

Cite this article as: Aggarwal M, Juneja S, Goyal M, Khurana T. A cross sectional observational study to find the difference in occurrence of muscle related adverse effects of statins among geriatric and nongeriatric patients. Int J Basic Clin Pharmacol 2018;7:1817-21. 